\title{
Pengaruh kompetensi, motivasi, lingkungan kerja dan persepsi gaya kepemimpinan terhadap kinerja penyuluh keluarga berencana
}

\author{
The impact of competence, motivation, work environment, and \\ leadership style toward family planning counselors performance
}

\author{
Nur Dwi Pujivanto, Dyah Retna Puspita, Bambang Tri Harsanto \\ Magister Ilmu Administrasi, Fakultas Ilmu Sosial dan Ilmu Politik \\ Universitas Jenderal Soedirman \\ Jalan Prof. Dr. H.R Boenyamin 993 Purwokerto, 53122 \\ E-mail: dwi_style@yahoo.com
}

\begin{abstract}
Nowadays the Family Planning Extension (PKB) still plays crucial role in supporting the success of population programs and family development. The implementation of decentralization policies that impacting existence of family planning programs is interesting for further analysis in their relation to the performance of PKB. In Kabupaten Pemalang, their performance is still relatively good. This good performance due to a number of factors such as competence, work motivation, work environment and leadership style perception. This study aims to examine to what extent the influence of four variables on the performance of PKB as a single or common variables. The research used a quantitative approach. Research populations are PKB members which consist of 93 people, all of which are sampled (total sample technique). Data obtained through questionnaires which then analyzed using simple linear regression test and multiple linear regression with the help of SPSS version 20 program. The results showed there is a significant influence of competence on PKB performance of 44.7 percent. Similarly, the work motivation, work environment and perceptions of the leadership style of supervisors individually influence the performance of $P K B$ respectively by 15.3 percent, 39.7 percent and 18.4 percent. These four variables also affect the performance of PKB of 52.8 percent. The research concluded that the effort to improve the performance of PKB in Pemalang Regency is by increasing the competence of PKB through education and training activities, support facilities and work infrastructure and execution of tasks democratic. Another effort is to provide encouragement and appreciation.
\end{abstract}

Keywords: competence, work motivation, work environment, leadership style perception, PKB performance

\begin{abstract}
Abstrak
Sampai saat ini Penyuluh Keluarga Berencana (PKB) masih berperan dalam menunjang keberhasilan program kependudukan dan pembangunan keluarga. Diterapkannya kebijakan desentralisasi yang berdampak terhadap eksistensi program KB, menarik untuk dikaji lebih lanjut dalam kaitannya dengan kinerja PKB. Di Kabupaten Pemalang, kinerja mereka relatif masih tetap tinggi. Hal ini diduga disebabkan oleh sejumlah faktor seperti kompetensi, motivasi kerja, lingkungan kerja dan persepsi gaya kepemimpinan. Untuk itulah, penelitian ini bertujuan untuk mengkaji seberapa besar pengaruh ke-empat variabel tersebut terhadap kinerja PKB, baik secara sendiri maupun bersama-sama. Pendekatan penelitiannya adalah kuantitatif di mana populasinya adalah para PKB yang berjumlah 93 orang yang kesemuanya dijadikan sampel (teknik sampel jenuh). Data diperoleh melalui kuesioner yang selanjutnya dianalisis menggunakan uji statistik regresi linier sederhana dan regresi linier berganda dengan bantuan program SPSS versi 20. Hasil penelitian menunjukkan adanya pengaruh yang positif dan signifikan dari kompetensi terhadap kinerja PKB sebesar 44,7 persen. Demikian halnya dengan motivasi kerja, lingkungan kerja dan persepsi atas gaya kepemimpinan atasan berpengaruh secara sendirisendiri terhadap kinerja PKB masing-masing sebesar15,3 persen, 39,7 persen dan 18,4 persen. Keempat variabel ini juga berpengaruh secara bersama-sama terhadap kinerja PKB sebesar 52,8 persen dari hasil ini disimpulkan bahwa upaya meningkatkan kinerja PKB di Kabupaten Pemalang ini adalah dengan meningkatkan kompetensi PKB melalui kegiatan pendidikan dan pelatihan, dukungan sarana dan prasarana kerja dan pelaksanaan tugas secara demokratis. Upaya lainnya adalah dengan memberikan dorongan dan penghargaan.
\end{abstract}

Kata kunci: kompetensi, motivasi kerja, lingkungan kerja, persepsi gaya kepemimpinan, kinerja PKB 


\section{Pendahuluan}

Undang-Undang Republik Indonesia Nomor 52 tahun 2009 tentang Perkembangan Kependudukan dan Pembangunan Keluarga mengamanatkan bahwa salah satu pembangunan sumber daya manusia Indonesia adalah melalui pengendalian jumlah penduduk. Indonesia merupakan negara dengan jumlah penduduk terbesar ke-empat setelah Cina, India, dan Amerika Serikat. Berdasarkan data Sensus Penduduk tahun 2010 jumlah penduduk Indonesia sebesar 237.641.334 jiwa dengan laju pertumbuhan penduduk sebesar 1,49 persen per tahun. Pertumbuhan penduduk yang tinggi akan menghambat laju pembangunan di berbagai bidang, oleh karena itu upaya untuk menurunkan tingkat kelahiran perlu ditingkatkan. Tingginya pertumbuhan penduduk ini dapat diatasi salah satunya dengan pengaturan kehamilan melalui Program Keluarga Berencana (Rismawati 2015).

Sejak dilaksanakan pada tahun 1970, program KB secara efektif mampu menurunkan angka kelahiran penduduk di Indonesia. Pada periode 1970-2004, angka kelahiran total (total fertility rate) wanita Indonesia berhasil diturunkan dari 5,6 per wanita menjadi 2,6 per wanita. Laju pertumbuhan penduduk nasional menurun dari 2,34 persen pada periode 1971-1980 menjadi 1,49 persen pada periode 1991-2000. Angka prevalensi pemakaian kontrasepsi juga berhasil ditingkatkan dari 15 persen pada tahun 1970 menjadi 61 persen pada tahun 2004 (Kurniawan 2009).

Sejak tahun 2004, ketika kebijakan Desentralisasi mulai diberlakukan, Program KB tampak menyurut di lapangan. Pelaksanaan Program KB pada era reformasi dipengaruhi oleh berbagai lingkungan strategis. Paradigma baru dalam sistem pemerintahan Indonesia yang tertuang dalam UndangUndang Nomor 22 Tahun 1999 yang diubah menjadi Undang-Undang Nomor 32 Tahun 2004 dan diubah lagi menjadi Undang-Undang Nomor 12 Tahun 2008 tentang perubahan kedua UndangUndang Nomor 32 Tahun 2004 tentang Pemerintahan Daerah telah mengubah posisi Program Keluarga Berencana yang sebelumnya menjadi kewenangan Pemerintah Pusat menjadi kewenangan Pemerintah Kabupaten/Kota, termasuk dalam hal ini adalah pengelolaan program di lini lapangan.

Sebagai dampak dari Undang-Undang Nomor 32 Tahun 2004, maka sebagian urusan pemerintahan di bidang Keluarga Berencana di tingkat Kabupaten/Kota diserahkan ke Pemerintah Kabupaten/ Kota pada tahun 2004 (Joniwar \& Heriyanto 2012). Desentralisasi diakui sebagai salah satu titik lemah BKKBN, akibatnya Program KB menghadapi tantangan yang luar biasa berat, karena secara kelembagaan di tingkat Kabupaten/Kota digantikan dengan lembaga yang ada di daerah (Alimoeso 2013).

Kondisi lain yang terjadi di era desentralisasi adalah berkurangnya jumlah penyuluh KB, baik karena beralih tugas menjadi pejabat struktural di tingkat kabupaten/kota/kecamatan, menjadi tenaga administrasi maupun karena pensiun. Menurunnya program KB juga tampak dari hasil studi empiris. Hasil Survei Demografi dan Kependudukan Indonesia (SDKI) tahun 2012 menunjukkan angka total fertility rate (TFR) Indonesia saat ini tetap (stagnant) dan tidak menunjukkan tren menurun, yaitu tetap pada angka 2,6 per wanita dalam kurun waktu 10 tahun (2002-2012). Hasil survey ini menunjukkan bahwa TFR di daerah perdesaan $(2,8)$, angkanya 17 persen lebih tinggi dibandingkan dengan daerah perkotaan $(2,4)$. Hal itu berpotensi menyebabkan terjadinya peledakan angka kelahiran (baby booming) dalam beberapa dekade mendatang, ketika bayi yang dilahirkan pada kohort sekarang, tiba saatnya mereka dewasa dan bereproduksi (BKKBN, BPS \& Kementerian Kesehatan 2013).

Berbagai kondisi di atas menyebabkan terbengkalainya aktifitas penyuluhan KB. Harapan besar yang dibebankan kepada PKB ternyata masih diliputi berbagai masalah yang menyangkut kinerja PKB di lapangan, antara lain: kemampuan manajemen yang terbatas, pelaksanaan tugas yang berorientasi angka kredit, pengetahuan dan wawasan tentang program KB yang terbatas, kemampuan mendorong partisipasi masyarakat yang tidak merata, penampilan kerja yang belum memadai dan rasio PKB terhadap jumlah desa/kelurahan binaan yang kurang tepat (Kurniawan 2009). 
Dari aspek kualitas dan teknis program, juga ditemui berbagai kendala. Hasil studi Focus Group Discussion (FGD) dengan PKB Provinsi DKI Jakarta, NTB, dan Kepulauan Riau ditemukan berbagai masalah, antara lain: 1) kelembagaan KB tidak menentu dan standar kinerja yang tidak jelas, 2) status PKB ambivalen antara aparat BKKBN dan aparat Pemerintah Kabupaten/Kota, sehingga standar dan prioritas tidak jelas, 3) dana operasional PKB sangat menurun akibat BKKBN berintegrasi dengan Dinas/Instansi lain terutama di Kabupaten/Kota dengan pendapatan asli daerah (PAD) yang rendah, 4) tugas dan fungsi PKB melebur dengan program lain, 5) program KB bukan lagi unggulan, akibat pimpinan tidak berasal dari BKKBN, 6) tanpa divisi supervisi menurunkan upaya pembinaan dan evaluasi PKB, 7) penguatan kapasitas PKB kurang diperhatikan, 8) tidak ada pemantauan stok kontrasepsi di Puskesmas (Kurniawan 2009).

Berbagai permasalahan tersebut dikhawatirkan akan menimbulkan dampak negatif terhadap Program KB, seperti iklim kerja yang tidak nyaman, pudarnya Norma Keluarga Kecil Bahagia Sejahtera (NKKBS) serta adanya keluarga miskin yang tidak terlayani akibat kehabisan stok alat kontrasepsi. Kemungkinan dampak lainnya adalah ledakan jumlah kelahiran dan isu multi-aspek ledakan penduduk yang berimbas pada kriminalitas, kemiskinan, kekurangan jumlah sekolah dan lain sebagainya.

Provinsi Jawa Tengah merupakan salah satu Provinsi di Indonesia yang terdiri dari 35 kabupaten/kota. Berdasarkan Data Sensus Penduduk tahun 2010 Jawa Tengah memiliki 32.382.657 jiwa penduduk. Menurut angka sementara Proyeksi Sensus Penduduk 2010, jumlah penduduk Jawa Tengah pada tahun 2014 adalah sejumlah 33.522.663 jiwa (13,29 persen dari jumlah penduduk Indonesia). Ini menempatkan Provinsi Jawa Tengah sebagai Provinsi ketiga di Indonesia dengan jumlah penduduk terbanyak setelah Provinsi Jawa Barat dan Jawa Timur (BPS Jawa Tengah 2015). Angka kelahiran di Jawa Tengah berdasarkan hasil SDKI tahun 2007 adalah sebesar 2,6 kelahiran per perempuan usia produktif 15-49 tahun. Adapun berdasarkan hasil SDKI tahun 2012 adalah sebesar 2,5.

Salah satu kabupaten di provinsi ini adalah Kabupaten Pemalang yang berada di jalur Pantai Laut Utara (Pantura) bersebelahan dengan Kota Pekalongan, Kabupaten Tegal dan Kabupaten Purbalingga. Pada tahun 2012 jumlah penduduknya adalah sebanyak 1.274.475 jiwa, tahun 2013 sebesar 1.279.596 jiwa dan tahun 2014 bertambah menjadi 1.284.236 jiwa (BPS Kabupaten Pemalang 2015). TFR di kabupaten ini menunjukan tren yang naik, dari 1,77 di tahun 2012 menjadi 2,3 di tahun 2013 dan naik lagi menjadi 2,39 di tahun 2014. Akan tetapi, angka ini masih berada di bawah angka TFR Provinsi Jawa Tengah (Pemerintah Kabupaten Pemalang 2013; 2014; 2015).

Program Kependudukan dan Keluarga Berencana (KKB) di Kabupaten Pemalang dikelola oleh Badan Pemberdayaan Masyarakat dan Keluarga Berencana Kabupaten Pemalang yang disingkat Bapermas dan KB. Program Kependudukan dan KB dikelola oleh salah satu bidang pada SKPD tersebut yaitu Bidang Keluarga Berencana. PKB mempunyai tugas melaksanakan fungsi manajemen pengelolaan program kependudukan dan KB Nasional di lini lapangan, meliputi: perencanaan, pengorganisasian, pelaksanaan, pembinaan, evaluasi dan pelaporan yang dijabarkan dalam 10 (sepuluh) langkah kerja PKB. Ke-10 langkah kerja ini meliputi: Planning (Pendekatan Tokoh Formal, Pendataan dan Pemetaan, Pendekatan Tokoh Informal), Organizing (Pembentukan kesepakatan dan pemantapan kesepakatan), Actuating (Komunikasi, Informasi, Edukasi, Pembentukan Group Pelopor, Pelayanan KB, Bidang Keluarga Sejahtera), Controlling (Pembinaan Keluarga dan Pencatatan, Pelaporan, Evaluasi) (BKKBN 2015).

Jumlah PKB yang ada di Kabupaten Pemalang pada tahun 2015 adalah sebanyak 93 orang yang ditempatkan di 14 Kecamatan dengan 222 desa/kelurahan. Dengan demikian, rasio PKB dengan desa/kelurahan adalah 2-3 yang artinya satu orang PKB membina dua sampai tiga desa/kelurahan. Padahal, menurut Peraturan Kepala BKKBN Nomor: 55/HK-010/B5/2010 tentang Standar Pelayanan Minimal Bidang Keluarga Berencana dan Keluarga Sejahtera di Kabupaten/Kota, 1 (satu) orang PKB membina 2 (dua) desa/kelurahan (BKKBN 2010). 
Meskipun kondisi PKB penuh dengan keterbatasan, akan tetapi capaian pelaksanaan Program KB di Kabupaten Pemalang dapat tercapai dengan baik. Hal tersebut dapat dilihat pada tabel di bawah ini:

Tabel 1.

Realisasi indikator kinerja daerah aspek pelayanan umum fokus layanan urusan wajib Keluarga Berencana dan Keluarga Sejahtera

\begin{tabular}{llccc}
\hline \multirow{2}{*}{ No } & \multicolumn{1}{c}{ Indikator Kinerja } & $\mathbf{3}$ Capaian \\
& \multicolumn{1}{c}{$\mathbf{2 0 1 2}$} & $\mathbf{2 0 1 3}$ & $\mathbf{2 0 1 4}$ \\
\hline 1. & Rata-rata jumlah anak per keluarga & 1,77 & 2,3 & 2,39 \\
2. & Cakupan Peserta KB aktif (\%) & 76,40 & 80,51 & 80,75 \\
3. & Unmeetneed (\%) & 12,03 & 14,77 & 10,22 \\
4. & $\begin{array}{l}\text { Peserta KB aktif yang tergabung dalam UPPKS } \\
\text { (\%) }\end{array}$ & 74,26 & 64,40 & 72,14 \\
5. & Rasio PKB dengan Desa/Kelurahan (orang) & $1: 3-4$ & $1: 3-4$ & $1: 2-3$ \\
6. & $\begin{array}{l}\text { Prosentase keluarga Pra Sejahtera/Sejahtera1 } \\
\text { (\%) }\end{array}$ & 53,00 & 53,80 & 52,67 \\
7. & Cakupan PUS dengan istri Usia $\leq 20$ tahun (\%) & 2,62 & 2,92 & 3,32 \\
\hline
\end{tabular}

Sumber: LKPJ Bupati Pemalang 2012-2014

Berdasarkan tabel 1 tampak bahwa rata-rata jumlah anak per keluarga menunjukan tren yang meningkat dari 1,71 (tahun 2012) menjadi 2,3 (tahun 2013) dan meningkat lagi mejadi 2,39 (tahun 2014). Pada tahun 2012-2014, capaian peserta KB aktif (contraception prevalence rate) terus meningkat dari 76,40 persen (2012) menjadi 80,51 persen (2013) dan 80,75 persen (2014). Baiknya kinerja PKB juga dapat dilihat dari angka unmeetneed. Unmeetneed adalah proporsi wanita usia subur dalam status kawin yang tidak menggunakan alat kontrasepsi meskipun mereka menyatakan ingin menunda atau menjarangkan anak dan mereka yang ingin membatasi kelahiran atau tidak menginginkan anak lagi (BKKBN 2013). Pada tahun 2012 angkanya 12,03 meningkat menjadi 14,77 di tahun 2013, akan tetapi menurun menjadi 10,22 di tahun 2014. Sementara itu, rasio PKB dengan jumlah desa/kelurahan binaan pada tahun 2012-2013 adalah 1: 3-4, sedangkan tahun 2014 rasionya menjadi 1: 2-3. Hal ini menunjukkan adanya penambahan tenaga PKB di tahun 2014.

Prosentase Peserta KB aktif yang tergabung dalam kelompok UPPKS pada tahun 2012 adalah sebesar 74,26 persen, akan tetapi menurun menjadi 64,40 persen di tahun 2013, namun kembali meningkat di tahun 2014 menjadi 72,12 persen. Prosentase keluarga Pra Sejahtera/Sejahtera 1 pada tahun 2012 adalah sebesar 53 persen, meningkat menjadi 53,80 persen di tahun 2013, akan tetapi menurun menjadi 52,67 persen di tahun 2014. Cakupan Pasangan Usia Subur (PUS) yang istrinya berusia di bawah 20 tahun menunjukkan tren yang meningkat dari 2,62 persen di tahun 2012 menjadi 2,9 persen di tahun 2013 dan meningkat lagi menjadi 3,32 persen di tahun 2014. Meningkatnya tren cakupan PUS ini disebabkan perilaku masyarakat yang belum sepenuhnya mematuhi UU Nomor 52 Tahun 2009 yang menyebutkan batas usia nikah bagi perempuan 20 tahun dan bagi laki-laki 25 tahun. Hal ini disebabkan adanya dispensasi dari orang tua untuk menikahkan anaknya yang masih berusia di bawah 20 tahun.

Perubahan lingkungan strategis, khususnya setelah penyerahan kewenangan penyelenggaraan program Kependudukan dan KB pada Pemerintah Kabupaten/Kota sangat berdampak terhadap pelaksanaan program. Akibat melemahnya komitmen dan dukungan politis terhadap kelembagaan, staffin serta dukungan dana dan sarana bagi penyelenggaraan Program Kependudukan dan KB di daerah, pelaksanaan program KB menjadi melemah. Hal ini dikhawatirkan melemahkan prestasi kerja yang telah diraih dan dibangun lebih dari 30 tahun. 
Salah satu faktor yang diduga mempengaruhi baiknya kinerja PKB di Kabupaten Pemalang adalah kompetensi dari PKB itu sendiri. Kinerja organisasi dapat meningkat apabila memiliki sumber daya manusia yang baik dan mumpuni. Hal ini dapat dilihat dari latar belakang pendidikan PKB/PLKB di Kabupaten Pemalang sebagai berikut:

Tabel 2.

Tingkat pendidikan PKB tahun 2015

\begin{tabular}{cccc}
\hline No. & Pendidikan terakhir & Jumlah & Prosentase (\%) \\
\hline 1. & SMP & 1 & 1,05 \\
2. & SMA & 46 & 48,42 \\
3. & Perguruan Tinggi (D1, D2, D3, S.1) & 48 & 50,53 \\
\hline & Jumlah & 95 & 100 \\
\hline
\end{tabular}

Sumber: Bapermas dan KB Kabupaten Pemalang 2015

Berdasarkan data pada tabel 2 dapat diketahui komposisi pendidikan terakhir PKB di Kabupaten Pemalang didominasi oleh jenjang Perguruan Tinggi (D1, D2, D3, dan S1). Hal ini menunjukkan bahwa tingkat pendidikan PKB di Kabupaten Pemalang sudah baik. Tingkat pendidikan PKB dapat mempengaruhi kinerjanya dalam melaksanakan tugas dan tanggung jawab di lini lapangan.

Selain faktor kompetensi, faktor motivasi kerja mempunyai peranan yang penting dalam hal menumbuhkan gairah dan semangat untuk bekerja secara optimal. PKB yang memiliki motivasi kerja yang tinggi akan mempunyai banyak energi untuk melaksanakan pekerjaannya. Oleh karena itu, motivasi kerja merupakan faktor yang sangat menentukan keberhasilan PKB dalam melaksanakan tugas yang dibebankan organisasi kepadanya.

Atas dasar itu, motivasi kerja juga diduga mempengaruhi kinerja PKB di Kabupaten Pemalang. Hal ini terkait dengan upaya yang dilakukan Pemerintah Kabupaten Pemalang untuk menjaga motivasi kerja PKB yakni dengan memberikan Tambahan Penghasilan Pegawai (TPP) yang merupakan penghasilan di luar gaji. Besaran Tambahan Penghasilan Pegawai (TPP) bagi PKB di Kabupaten Pemalang pada tahun 2015 sebesar Rp. 100.000 yang diberikan setiap bulan.

Faktor lain yang mempengaruhi kinerja PKB adalah faktor lingkungan kerja. Perubahan lingkungan fisik $\mathrm{PKB}$, seperti ketersediaan sarana dan prasarana yang menunjang pelaksanaan tugas PKB juga diduga mempengaruhi kinerja PKB. Di Kabupaten Pemalang, dengan keterbatasan anggaran yang ada, sarana dan prasarana yang dibutuhkan untuk menunjang pelaksanaan tugas PKB di lini lapangan berusaha dipenuhi oleh Pemerintah Kabupaten Pemalang. Hal ini bisa dilihat dari daftar aset Bapermas dan KB Kabupaten Pemalang sebagai berikut:

Tabel 3.

Daftar aset kendaraan dinas roda dua dan gedung Balai Penyuluhan KB tahun 2015

\begin{tabular}{clc}
\hline No. & \multicolumn{1}{c}{ Nama aset } & Jumlah \\
\hline 1. & Kendaraan Dinas Roda 2 & 131 buah \\
2. & Gedung dan Bangunan Balai Penyuluhan & 11 unit
\end{tabular}

\section{Sumber: Bapermas dan KB Kabupaten Pemalang 2015}

Tabel 3 menunjukkan bahwa sarana berupa kendaraan dinas roda dua berjumlah 131 buah, 95 buah digunakan untuk PKB dan 14 buah digunakan untuk Kepala UPKB dan PP. Adapun sisanya sebanyak 22 buah digunakan oleh staff di Bapermas dan KB Kabupaten Pemalang. Sarana lainnya yang sudah diupayakan Pemkab adalah gedung dan Balai Penyuluhan KB yang sudah ada di tiap semua kecamatan.

Faktor lain yang turut mempengaruhi kinerja PKB adalah perubahan lingkungan sosial. Lingkungan 
sosial yang dimaksud adalah dukungan stakeholder di tingkat kecamatan dan desa/kelurahan. Dengan keterbatasan anggaran yang ada, maka frekuensi rapat koordinasi di tingkat kecamatan (Rakorcam) maupun di tingkat desa/kelurahan (Rakordes) menjadi berkurang. Pembinaan terhadap Institusi Masyarakat Perdesaan (IMP), seperti PPKBD (Pembantu Pembina KB Desa), Sub PPKBD, dan Kelompok KB juga tidak bisa dilaksanakan secara rutin. Agar PKB tetap mendapat dukungan dari para stakeholder di tingkat kecamatan dan desa/kelurahan, mereka memanfaatkan forum-forum kegiatan yang sudah ada di tingkat desa/kelurahan dan di tingkat kecamatan, sehingga pelaksanaan rapat koordinasi tetap berjalan sebagaimana mestinya.

Dukungan program kependudukan dan KB dari pemerintah kabupaten/kota juga diduga berdampak pada kinerja PKB. Pada era otonomi daerah dengan adanya pelaksanaan pemilihan kepala daerah (Pilkada) secara langsung, Bupati/Walikota biasanya lebih memprioritaskan pembangunan fisik karena hasilnya dapat langsung terlihat dan dirasakan oleh masyarakat dalam periode kepemimpinannya. Harapannya adalah agar dapat dipilih kembali pada periode berikutnya. Hal ini berbeda dengan jika fokusnya pada pembangunan kependudukan dan KB, karena hasilnya baru dapat dirasakan dalam jangka waktu yang relatif lama.

Selain faktor-faktor yang telah disebutkan sebelumnya, faktor lain yang mempengaruhi kinerja PKB adalah gaya kepemimpinan dari atasan langsung PKB. Keberhasilan atau kegagalan suatu organisasi sebagian besar ditentukan oleh pemimpin dan kepemimpinannya. Hal ini menunjukkan bahwa posisi kepemimpinan dalam suatu organisasi sangat penting. Keberhasilan atau kegagalan tersebut tergantung berhasil tidaknya pemimpin mengelola sumber daya manusianya. Di era Otonomi Daerah, Bupati selaku Pejabat Pembina Kepegawaian memiliki kewenangan untuk menempatkan pejabat struktural sesuai dengan kebutuhan organisasi. Banyak Pejabat daerah yang ditempatkan pada jabatan tertentu tetapi tidak sesuai dengan kompetensi yang dimiliki dikarenakan adanya unsur politis yang turut mempengaruhi. Sementara itu, penempatan para Kepala UPKB dan PP di Kabupaten Pemalang dirasa sudah sesuai karena mayoritas Kepala UPKB dan PP sejumlah 13 orang berasal dari PKB, dan hanya 1 orang yang berasal dari pindahan Kepala Seksi Tata Pemerintahan di kecamatan. Kondisi ini juga diduga berdampak pada capaian kinerja PKB.

PKB sebagai pengelola program Kependudukan dan KB Nasional di Desa/Kelurahan, dituntut untuk dapat mengembangkan potensi dirinya, sehingga mau dan mampu menghadapi setiap perubahan lingkungan kerja yang terjadi. Di samping itu juga memiliki kesanggupan/komitmen untuk berubah sesuai dengan situasi dan kondisi yang ada. Beberapa data mengenai capaian kinerja PKB di Kabupaten Pemalang di atas menunjukkan kinerja PKB di Kabupaten Pemalang termasuk dalam kategori baik karena dengan segala keterbatasan yang ada ternyata pelaksanaan programnya dapat berjalan dengan baik. Untuk itu, menarik untuk dikaji lebih jauh kinerja PKB Kabupaten Pemalang beserta faktor-faktor yang mempengaruhinya. Dengan demikian, tujuan penelitian ini adalah untuk mengkaji kinerja PKB Kabupaten Pemalang saat ini serta mengkaji bagaimana pengaruh kompetensi, motivasi, lingkungan kerja dan persepsi gaya kepemimpinan terhadap kinerja mereka baik secara sendiri maupun secara bersama-sama.

\section{Metode penelitian}

Kinerja adalah hasil yang diinginkan dari perilaku dan kinerja individu adalah dasar kinerja organisasi (Gibson et al. 1996). Kinerja yang tinggi dapat disebabkan oleh banyak faktor. Menurut Gibson, kinerja individu disebabkan oleh tiga faktor, yakni: (1) faktor individu, meliputi: kemampuan, ketrampilan, latar belakang keluarga, pengalaman kerja, tingkat sosial dan demografi, (2) faktor psikologis, meliputi: persepsi, peran, sikap, kepribadian, motivasi dan kepuasan kerja, dan (3) faktor organisasi: struktur organisasi, desain pekerjaan, kepemimpinan dan sistem penghargaan. Adapun Ainsworth et al. (2002) menyebutkan bahwa faktor-faktor yang mempengaruhi kinerja adalah: kejelasan peran (role clarity), kompetensi (competence), lingkungan (environment), nilainilai (values), kecenderungan (preferences) dan penghargaan (reward) yang dirumuskan dengan $\mathrm{P}=(\mathrm{Rc}, \mathrm{C}, \mathrm{E}, \mathrm{V}, \mathrm{Pf}, \mathrm{Rw})$. Sementara itu, menurut Robbins (1996), kinerja tidak saja ditentukan oleh kedua faktor tersebut, melainkan juga oleh kesempatan (opportunity). Jadi, kinerja adalah fungsi 
interaksi antara kemampuan atau ability (A), motivasi atau motivation (M) dan kesempatan atau opportunity $(\mathrm{O})$, atau kinerja $=f(\mathrm{~A}, \mathrm{M}, \mathrm{O})$. Dalam penelitian ini, faktor-faktor yang akan dikaji adalah kompetensi, motivasi, lingkungan kerja dan persepsi terhadap gaya kepemimpinan atasan.

Penelitian dilaksanakan di Kabupaten Pemalang dengan sasaran para PKB pada instansi Bapermas dan KB Kabupaten Pemalang. Jenis penelitiannya adalah penelitian asosiatif dengan pendekatan kuantitatif menggunakan metode survei. Data dikumpulkan melalui pembagian kuesioner yang dibuat secara tertutup (terstruktur) didukung dengan wawancara dan dokumentasi.

Populasi penelitian adalah PKB dan PLKB di Kabupaten Pemalang pada tahun 2016 yang berjumlah 93 orang. Teknik pengambilan sampel menggunakan teknik sampling jenuh yakni mengambil semua anggota populasi untuk sampel. Uji validitas dan reliabilitas kuesioner dilakukan terhadap 30 orang PKB di Kabupaten Pemalang. Uji validitas kuesioner menggunakan teknik korelasi product moment, sedangkan uji reliabilitas kuesioner menggunakan rumus alpha cronbach. Data yang telah terkumpul selanjutnya dianalisis menggunakan bantuan software SPSS for windows versi 20. Teknik analisis datanya adalah analisis deskriptif, uji korelasi product moment, uji asumsi klasik (uji heteroskedastisitas, uji multikolinearitas, uji autokorelasi dan uji normalitas data), uji regresi linear sederhana serta uji regresi linear berganda.

\section{Hasil Penelitian dan Pembahasan}

\section{Kinerja PKB di Kabupaten Pemalang}

Penelitian menunjukkan bahwa dari 93 responden penelitian, mayoritas dari mereka ( 88 responden atau 94,6 persen) memiliki kinerja baik, 5 responden (5,4 persen) memiliki kinerja sedang serta tidak ada responden yang memiliki kinerja buruk $(0,0 \%)$. Pengukuran kinerja PKB dalam penelitian ini dilihat dari sejumlah indikator yakni kualitas, kuantitas, ketepatan waktu, kreatifitas, kemampuan bekerja sama dan kehadiran (Malthis \& Jackson 2006, Gomes 2003).

Angka rata-rata tertinggi jawaban responden adalah pada indikator kemampuan bekerja sama yakni sebesar 4,21. Indikator kemampuan bekerja sama diukur dari kemampuan PKB dalam bekerja sama dengan rekan kerja dan lingkungannya yang dilihat dari kemampuan memelihara hubungan baik dengan atasan dan rekan kerjanya, kemampuan bekerja tim, saling memberikan bantuan/dukungan kepada rekan kerja dan kemampuan melakukan pendekatan kepada tokoh formal, tokoh agama dan tokoh masyarakat.

\section{Pengaruh kompetensi terhadap kinerja PKB di Kabupaten Pemalang}

Hasil uji regresi linear sederhana membuktikan bahwa kompetensi berpengaruh signifikan terhadap kinerja PKB di Kabupaten Pemalang sebesar 0,669. Nilai koefisien determinan ( $R$ Square) sebesar 0,447 atau 44,7 persen. Hal ini berarti bahwa variabel kompetensi $\left(\mathrm{X}_{1}\right)$ hanya dapat menjelaskan perubahan kinerja PKB (Y) sebesar 44,7 persen, sedangkan 55,3 lainnya dipengaruhi oleh variabel lain. Berdasarkan nilai pada output coefficient diperoleh persamaan regresi linear sederhana sebagai berikut :

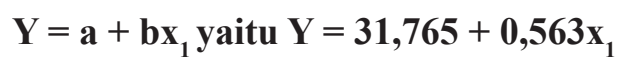

Nilai koefisien regresi sebesar 0,563 menunjukkan bahwa setiap perubahan satu satuan nilai variabel kompetensi akan meningkatkan nilai variabel kinerja sebesar 0,563 . Hasil penelitian ini membuktikan bahwa semakin baik kompetensi PKB, akan semakin baik pula kinerjanya. Setiap peningkatan kompetensi PKB akan memberikan peningkatan yang sangat berarti bagi peningkatan kinerja PKB dalam melaksanakan pekerjaanya. Variabel kompetensi mempunyai pengaruh yang kuat terhadap kinerja $\mathrm{PKB}$, sehingga pengelola Program KB harus memperhatikan variabel kompetensi PKB dalam pengambilan kebijakan guna mempertahankan dan meningkatkan kinerja PKB. 
Rata-rata tertinggi jawaban responden adalah pada indikator relasi interpersonal. Kompetensi relasi interpersonal dilihat dari kemampuan berinteraksi dengan berbagai individu dan kelompok yang berbeda untuk menciptakan kemitraan, jejaring, dan sistem kemanusiaan yang dinamis. PKB harus mampu menjalin hubungan dengan para stakeholder di tingkat kecamatan dan desa/kelurahan, membina hubungan dan kerja sama dengan tokoh masyarakat dan tokoh agama guna meminta dukungan dalam pelaksanaan program KB.

Gibson et al. (1996) kinerja seseorang dipengaruhi oleh faktor individu, faktor psikologis dan faktor organisasi. Salah satu faktor individu yang mempengaruhi kinerja seseorang adalah faktor kemampuan atau kompetensi yang dimiliki oleh pegawai. Puspita (2011) menyatakan kompetensi berpengaruh signifikan terhadap kinerja Aparatur Penyuluh KB di Jawa Barat. Keran (2012) menyatakan bahwa kompetensi memiliki pengaruh yang signifikan terhadap kinerja pegawai.

\section{Pengaruh motivasi kerja terhadap kinerja PKB di Kabupaten Pemalang}

Hasil uji regresi linear sederhana membuktikan bahwa motivasi kerja berpengaruh signifikan terhadap kinerja PKB di Kabupaten Pemalang sebesar 0,391. Nilai koefisien determinan ( $R$ Square) sebesar 0,153 atau 15,3 persen menunjukkan bahwa variabel motivasi kerja $\left(\mathrm{X}_{2}\right)$ hanya dapat menjelaskan perubahan kinerja PKB (Y) sebesar 15,3 persen, sedangkan 84,7 persen lainnya dipengaruhi oleh variabel lain. Berdasarkan nilai pada output coefficient diperoleh persamaan regresi linear sederhana sebagai berikut:

$$
Y=a+b x 2 \text { yaitu } Y=102,601+0,885 \times 2
$$

Nilai koefisien regresi sebesar 0,885 menunjukkan bahwa setiap perubahan satu satuan nilai variabel motivasi kerja akan meningkatkan nilai variabel kinerja sebesar 0,885 . Hasil penelitian membuktikan bahwa semakin tinggi motivasi kerja, akan semakin tinggi pula kinerjanya. Setiap peningkatan motivasi kerja akan memberikan peningkatan yang sangat berarti bagi peningkatan kinerja PKB dalam melaksanakan pekerjaannya.

Rata-rata tertinggi jawaban responden adalah pada indikator kesempatan berprestasi. Kesempatan berprestasi dilihat dari dorongan dan peluang PKB untuk memperoleh prestasi kerja yang baik, keinginan menjadi PKB teladan yang berhasil dalam memberikan pelayanan yang terbaik bagi masyarakat dan organisasi. Hasil penelitian sejalan dengan pendapat Mitchel (dalam Sedarmayanti 2001) yang menyatakan bahwa Human Performance = Ability +Motivation, yang artinya bahwa untuk mendapatkan gambaran tentang kinerja seseorang, maka perlu pengkajian khusus kemampuan dan motivasinya. Kinerja seseorang dipengaruhi oleh tiga faktor, yakni faktor individu, psikologis dan organisasi. Salah satu faktor psikologis yang mempengaruhi kinerja seseorang adalah motivasi kerja Gibson et al. (1996).

Hasil penelitian sejalan dengan penelitian Arif Dwiyantono (2008) yang menyatakan ada pengaruh yang signifikan antara motivasi dengan kinerja PLKB di Badan Kependudukan dan KB Kabupaten Jember. Hasil penelitian juga didukung oleh hasil penelitian senada yang dilakukan Puspita (2011), Hentry Sukmasari (2011), Marhari (2013), Wasriyati (2006), Keran (2012), Shimko (2012), Novyanti (2015) yang menyatakan bahwa terdapat pengaruh yang signifikan antara motivasi terhadap kinerja pegawai.

\section{Pengaruh lingkungan kerja terhadap kinerja PKB di Kabupaten Pemalang}

Hasil uji regresi linear sederhana membuktikan bahwa lingkungan kerja berpengaruh signifikan terhadap kinerja PKB di Kabupaten Pemalang sebesar 0,630. Nilai koefisien determinan ( $R$ Square) sebesar 0,397 atau 39,7 persen berarti bahwa variabel lingkungan kerja $\left(\mathrm{X}_{3}\right)$ hanya dapat menjelaskan 
perubahan kinerja PKB (Y) sebesar 39,7 persen, sedangkan 60,3\% persen lainnya dipengaruhi oleh variabel lain. Berdasarkan nilai pada output coefficient diperoleh persamaan regresi linear sederhana sebagai berikut:

$$
\mathrm{Y}=\mathbf{a}+\mathbf{b x}_{3} \text { yaitu } \mathrm{Y}=\mathbf{5 6 , 1 9 8}+\mathbf{0 , 9 7 4 x _ { 3 }}
$$

Nilai koefisien regresi sebesar 0,974 berarti bahwa setiap perubahan satu satuan nilai variabel lingkungan kerja akan meningkatkan nilai variabel kinerja sebesar 0,974. Hasil penelitian ini menunjukkan bahwa semakin baik lingkungan kerja maka kinerja PKB akan semakin baik, setiap peningkatan lingkungan kerja akan memberikan peningkatan yang sangat berarti bagi peningkatan kinerja PKB dalam melaksanakan pekerjaannya.

Rata-rata tertinggi jawaban responden, yaitu pada indikator lingkungan fisik. Lingkungan fisik dilihat dari ketersediaan sarana transportasi berupa kendaraan dinas roda dua, ketersediaan sarana komunikasi, alat peraga penyuluhan, dan ketersediaan alat kontrasepsi.

Kinerja ditentukan beberapa faktor salah satunya adalah lingkungan kerja (environment) Ainsworth et al. (2002). Mangkunegara (2005) menyatakan kinerja seseorang dipengaruhi oleh faktor individu dan faktor lingkungan. Hasil penelitian ini juga sejalan dengan penelitian Novyanti (2015), Puspita (2011) dan Shimko (2012).

\section{Pengaruh persepsi gaya kepemimpinan terhadap kinerja PKB di Kabupaten Pemalang}

Hasil uji regresi linear sederhana membuktikan bahwa persepsi gaya kepemimpinan berpengaruh signifikan terhadap kinerja PKB di Kabupaten Pemalang sebesar 0,429. Nilai koefisien determinan ( $R$ Square) sebesar 0,184 atau 18,4 persen berarti bahwa variabel persepsi gaya kepemimpinan $\left(\mathrm{X}_{4}\right)$ hanya dapat menjelaskan perubahan kinerja PKB (Y) sebesar 18,4 persen, sedangkan 81,6 persen lainnya dipengaruhi oleh variabel lain. Berdasarkan nilai pada output coefficient diperoleh persamaan regresi linear sederhana sebagai berikut :

$$
\mathrm{Y}=\mathbf{a}+\mathbf{b x}_{4} \text { yaitu } \mathrm{Y}=108,781+0,762 \mathbf{x}_{4}
$$

Nilai koefisien regresi sebesar 0,762 yang artinya setiap perubahan satu satuan nilai variabel lingkungan kerja akan meningkatkan nilai variabel kinerja sebesar 0,762 . Hasil penelitian ini menunjukkan bahwa semakin baik persepsi gaya kepemimpinan maka kinerja PKB akan semakin baik, setiap peningkatan nilai persepsi gaya kepemimpinan akan memberikan peningkatan yang sangat berarti bagi peningkatan kinerja PKB dalam melaksanakan pekerjaannya. Rata-rata tertinggi jawaban responden pada indikator pelaksanaan tugas. Pelaksanaan tugas dilihat dari pelaksanaan diskusi dengan bawahan dalam menentukan langkah-langkah kerja, mengutamakan kerja sama dalam pelaksanaan tugas, partisipasi pimpinan dalam kegiatan kelompok, penjelasan pembagian tugas kepada bawahan, dan pemberian perintah yang disertai dengan arahan dan bimbingan.

Gibson et al. (1996) menyatakan bahwa kinerja seseorang dipengaruhi oleh faktor individu, faktor psikologis dan faktor organisasi. Salah satu faktor organisasi yang mempengaruhi kinerja seseorang adalah faktor kepemimpinan. Temuan penelitian ini didukung oleh hasil penelitian Leni Evanita (2013), Marhari (2013), Wijaya \& Soedarmadi (2013), Sukmasari (2011) dan Shimko (2012).

\section{Pengaruh kompetensi, motivasi kerja, lingkungan kerja dan persepsi gaya kepemimpinan terhadap kinerja PKB di Kabupaten Pemalang}

Hasil uji regresi linear berganda membuktikan bahwa kompetensi, motivasi kerja, lingkungan kerja dan persepsi gaya kepemimpinan berpengaruh signifikan dan positif terhadap kinerja PKB di Kabupaten Pemalang. Nilai Signifikansi dan nilai F hitung dapat dilihat pada tabel 4: 
Tabel 4.

Signifikansi korelasi antar variabel

Korelasi Kompetensi $\left(\mathrm{X}_{1}\right)$, Motivasi Kerja $\left(\mathrm{X}_{2}\right)$, dan

Lingkungan kerja $\left(\mathrm{X}_{3}\right)$, dan Persepsi Gaya kepemimpinan

$\left(\mathrm{X}_{4}\right)$ terhadap Kinerja PKB $(\mathrm{Y})$

Sumber: data primer 2016

Berdasarkan tabel 4 dapat diketahui nilai F hitung sebesar 26,716 > dari F tabel 2,48 dan nilai Sig. sebesar 0,000 lebih kecil dari 0,05 sehingga dapat disimpulkan bahwa Ho ditolak dan Ha diterima yang artinya terdapat pengaruh bersama (majemuk) yang signifikan dan positif antara variabel kompetensi $\left(\mathrm{X}_{1}\right)$, motivasi kerja $\left(\mathrm{X}_{2}\right)$, lingkungan kerja $\left(\mathrm{X}_{3}\right)$ dan persepsi gaya kepemimpinan $\left(\mathrm{X}_{4}\right)$ dengan variabel kinerja PKB $(\mathrm{Y})$. Nilai koefisien regresi dalam penelitian ini dapat dilihat pada tabel 5 .

Tabel 5.

Koefisien regresi

\begin{tabular}{lcc}
\hline & $\mathrm{B}$ & Sig \\
\hline Konstanta & 9.601 & 0.467 \\
Kompetensi & .389 & 0.000 \\
Motivasi kerja & .114 & 0.631 \\
Lingkungan kerja & .388 & 0.016 \\
Persepsi Gaya kepemimpinan & .252 & 0.196 \\
\hline
\end{tabular}

Sumber: data primer 2016

Berdasarkan tabel 5 dapat disusun persamaan garis regresi linear berganda dalam penelitian ini sebagai berikut:

$$
Y=9,601+0,389 \times 1+0,114 \times 2+0,388 \times 3+0,252 \times 4
$$

Berdasarkan persamaan regresi tersebut, variabel yang paling dominan dan signifikan dalam mempengaruhi kinerja PKB di Kabupaten Pemalang(Y) adalah kompetensi (X1) dan lingkungan kerja (X3) dengan nilai koefisien regresinya yang paling besar yaitu sebesar 0,389 untuk X1 dan untuk X3 0,388 lebih besar jika dibandingkan dengan variabel motivasi kerja (X2) 0,114 dan variabel persepsi gaya kepemimpinan (X3) 0,252. Faktor yang paling dominan mempengaruhi kinerja PKB di Kabupaten Pemalang adalah kompetensi dan lingkungan kerja, sehingga para pemangku kebijakan dalam mengambil kebijakan perlu memperhatikan faktor tersebut supaya diperoleh kinerja PKB yang lebih baik. Hal ini didukung pendapat Timple dalam Mangkunegara (2007) yang mengungkapkan bahwa faktor kinerja terdiri dari dua faktor yaitu (1) faktor internal yang terkait dengan sifat-sifat seseorang misalnya kinerja baik disebabkan karena mempunyai kemampuan tinggi dan tipe pekerja keras, dan (2) faktor eksternal yang terkait dari lingkungan seperti perilaku, sikap dan tindakan rekan kerja, bawahan atau pimpinan, fasilitas kerja dan iklim organisasi.

Gibson et al. (1996) menyatakan bahwa kinerja dipengaruhi oleh faktor individu yaitu kemampuan dan ketrampilan, latar belakang, serta demografis; faktor organisasi yaitu sumberdaya, kepemimpinan, imbalan (kompensasi), struktur organisasi, dan diskripsi pekerjaan (job description); dan faktor psikologis yaitu persepsi, sikap (disiplin), kepribadian, pola belajar dan motivasi. Sejalan dengan itu, Ainsworth et al., (2002) menguraikan bahwa kinerja ditentukan beberapa faktor yakni: kejelasan peran (role clarity), kompetensi (competence), lingkungan (environment), nilai-nilai (values), kecenderungan (preferences) dan penghargaan (reward), yang dirumuskan: $\mathrm{P}=(\mathrm{Rc}, \mathrm{C}, \mathrm{E}, \mathrm{V}, \mathrm{Pf}, \mathrm{Rw})$.

Hasil penelitian ini mendukung penelitian Puspita (2011) tentang pengaruh motivasi, kompetensi, dan lingkungan kerja pada kinerja aparatur Penyuluh KB di Jawa Barat (Kabupaten Bogor, Kabupaten Cianjur, 
dan Kota Depok). Disebutkan, motivasi, kompetensi, dan lingkungan kerja berpengaruh terhadap kinerja aparatur penyuluh KB dalam melaksanakan penyuluhan dan pelayanan KB sebesar 0,64 atau 64 persen. Yulniwarti Shimko (2012) menyatakan terdapat pengaruh yang signifikan antara gaya kepemimpinan, motivasi, dan lingkungan kerja terhadap Kinerja Pegawai Negeri Sipil pada Kantor Pemerintah Kabupaten Solok Selatan Provinsi Sumatra Barat. Didukung juga oleh hasil penelitian Linawati dan Suhaji (2011) yang menyatakan terdapat pengaruh antara motivasi, kompetensi, kepemimpinan, dan lingkungan kerja terhadap kinerja karyawan pada PT. Herculon Carpet Semarang.

\section{Simpulan}

Dari analisis yang dilakukan, disimpulkan bahwa mayoritas PKB di Kabupaten Pemalang (84,6 persen) mempunyai kinerja yang baik. Hal ini secara positif dan signifikan dipengaruhi oleh variabel kompetensi sebesar 44,7 persen. Faktor pengaruh lainnya adalah motivasi kerja yang secara positif dan signifikan meski hanya mempengaruhi sebesar 15,3 persen. Variabel lingkungan kerja memberi pengaruh secara positif dan signifikan sebesar 39,7 persen. Adapun persepsi mereka terhadap gaya kepemimpinan atasan berpengaruh secara positif dan signifikan sebesar 18,4 persen. Di samping terdapat pengaruh keempat variabel tersebut secara sendiri-sendiri, terdapat juga pengaruh secara bersama-sama dari keempat variabel tersebut terhadap kinerja PKB di Kabupaten Pemalang sebesar 52,8 persen. Adapun 47,2 persen lainnya dipengaruhi oleh variabel lain diluar model penelitian ini.

\section{Daftar Pustaka}

Ainsworth MSS \& Millership A (2002) Managing Performance Managing People. Jakarta: PT. Bhuana Ilmu Populer.

Alimoeso S (2013) Pengaruh Implementasi Kebijakan Desentralisasi terhadap Kualitas Pelayanan Program Keluarga Berencana. Bunga Rampai Kependudukan IPADI. Jakarta: BKKBN Pusat.

Badan Koordinasi Keluarga Berencana Nasional (2010) Peraturan Kepala Badan Koordinasi Keluarga Berencana Nasional Nomor: 55/HK-010/B5/2010 tentang Standar Pelayanan Minimal Bidang Keluarga Berencana dan Keluarga Sejahtera di Kabupaten Kota. Jakarta: BKKBN.

Badan Koordinasi Keluarga Berencana Nasional (BKKBN) (2013) Survey Demografi dan Kesehatan Indonesia (SDKI) 2012. Jakarta: BKKBN.

Badan Koordinasi Keluarga Berencana Nasional (BKKBN) (2015) Tugas dan Fungsi PLKB/PKB, Pedoman Kerja Tenaga Lini Lapangan Program Kependudukan Keluarga Berencana dan Pemberdayaan Keluarga. Jakarta: Direktorat Bina Lini Lapangan BKKBN.

BPS Kabupaten Pemalang (2015) Pemalang dalam Angka 2015. Pemalang: BPS Pemalang.

BPS Jawa Tengah (2015) Jawa Tengah dalam Angka 2015. Semarang: BPS Provinsi Jawa Tengah.

Dwiyantono A (2008) Pengaruh profesionalisme dan motivasi kerja terhadap kinerja PLKB di Badan Kependudukan Keluarga Berencana dan catatan sipil Kabupaten Jember. Jurnal Tesis Prodi Administrasi Universitas Jember.

Gibson JL, John MI \& James HD (1996) Organisasi: Perilaku, Struktur, Proses. Jilid I, Edisi kedelapan. Jakarta: Bina Rupa Aksara.

Gomes FC (2002) Manajemen Sumber Daya Manusia. Yogyakarta: Penerbit Andi.

Joniwar \& Meyzi H (2012) Analisis efektivitas kinerja penyuluh lapangan. Jurnal Administrasi Pembangunan 1(1):1-100.

Keran KN (2012) Pengaruh motivasi kerja, kompetensi dan kompensasi terhadap kinerja karyawan di Yayasan Bintang Timur Tangerang. Tesis. Prodi MM Universitas Esa Unggul Jakarta.

Kurniawan UK (2009) Asesmen Efektivitas Kinerja Penyuluh Lapangan Keluarga Berencana (PKB) di 4 Provinsi di Indonesia (Jatim, DIY, Kepri, dan NTB). Bunga Rampai Kependudukan IPADI. Jakarta: BKKBN Pusat.

Linawati \& Suhaji (2011) Pengaruh Motivasi, Kompetensi, Kepemimpinan dan Lingkungan kerja terhadap Kinerja Karyawan (studi pada PT. Herculon Carpet Semarang). Semarang: STIE Widya Manggala. 
Malthis RL \& Jackson JH (2006) Human Resource Management (Manajemen Sumber Daya Manusia), Edisi 10. Jakarta: Salemba Empat.

Novyanti JS (2015) Pengaruh motivasi kerja, lingkungan kerja dan disiplin kerja terhadap kinerja pegawai pada Bappeda Provinsi Sulawesi Tengah. e-Jurnal Katalogis 3(1):105-115.

Pemerintah Kabupaten Pemalang (2013) Laporan Keterangan Pertanggungjawaban Bupati Pemalang Akhir Tahun Anggaran 2012. Pemalang: Pemerintah Kabupaten Pemalang.

Pemerintah Kabupaten Pemalang (2014) Laporan Keterangan Pertanggungjawaban Bupati Pemalang Akhir Tahun Anggaran 2014. Pemalang: Pemerintah Kabupaten Pemalang.

Pemerintah Kabupaten Pemalang (2015) Laporan Keterangan Pertanggungjawaban Bupati Pemalang Akhir Tahun Anggaran 2014. Pemalang: Pemerintah Kabupaten Pemalang.

Puspita DR (2011) Pengaruh motivasi, kompetensi dan lingkungan kerja pada kinerja aparatur penyuluh Keluarga Berencana. Jurnal Ilmu Administrasi Negara Universitas Riau, 11 (1):8696.

Rismawati S (2015) Unmetneed: Tantangan program Keluarga Berencana dalam menghadapi ledakan penduduk tahun 2030. Artikel Mahasiswa Magister Kebidanan UNPAD Bandung. [Diakses pada 23 Mei 2016]. http://pustaka.unpad.ac.id/wp-content/uploads/2014/10/artikel-unmetneed.pdf.

Sedarmayanti (2001) Sumberdaya Manusia dan Produktivitas Kerja. Bandung: Mandar maju.

Shimko Y (2012) Pengaruh gaya kepemimpinan, motivasi dan lingkungan kerja terhadap kinerja pengawai negeri sipil pada kantor pemerintah Kabupaten Solok Selatan, Sumatera Barat. Jurnal MM IBM ASMI 1(1):143-174.

Sukmasari H (2011) Pengaruh Kepemimpinan, Motivasi, Insentif, Lingkungan Kerja dan Kepuasan Kerja terhadap Kinerja Pegawai Dinas Pengelolaan Keuangan dan Aset Daerah Kota Semarang. Jurnal Tesis Magister Manajemen UDINUS Semarang.

Undang-undang Nomor 10 Tahun 1992 tentang Perkembangan Kependudukan dan Pembangunan Keluarga Sejahtera.

Undang-Undang Nomor 32 Tahun 2004 sebagaimana telah diamandemen dengan Undang-Undang Nomor 12 Tahun 2008 Tentang Pemerintahan Daerah.

UU Nomor 52 Tahun 2009 tentang Perkembangan Kependudukan dan Pembangunan Keluarga.

Undang-Undang Nomor 23 Tahun 2014 tentang Pemerintahan Daerah.

Wasriyati U (2006) Analisis faktor-faktor yang mempengaruhi kinerja penyuluh keluarga berencana dalam pelaksanaan program kependudukan dan KB di Kabupaten Gunung Kidul. Tesis, Magister Manajemen Universitas Muhammadiyah Yogyakarta. 